\title{
Anti-HIV Pozitif Bir Hastada Saptanan Akut Toskana Virus Enfeksiyonu*
}

\author{
Acute Toscana Virus Infection in an Anti-HIV Positive Patient
}

\author{
Ferit KUŞCU', Dilek MENEMENLiOĞLU², Doğan Barış ÖZTÜRK³ ${ }^{3}$ Gülay KORUKLUOĞLU², \\ Yavuz UYAR ${ }^{4}$
}

\footnotetext{
${ }^{1}$ Adana Numune Eğitim ve Araştırma Hastanesi, Enfeksiyon Hastalıkları ve Klinik Mikrobiyoloji Kliniği, Adana.

${ }^{1}$ Numune Educational and Research Hospital, Infectious Diseases and Clinical Microbiology Clinic, Adana, Turkey.

${ }^{2}$ Türkiye Halk Sağlığı Kurumu, Ulusal Viroloji Referans Merkez Laboratuvarı, Ankara.

2 Public Health Institution of Turkey, National Virology Reference Laboratory, Ankara, Turkey.

${ }^{3}$ Ulucanlar Göz Eğitim ve Araştırma Hastanesi, Enfeksiyon Hastalıkları ve Klinik Mikrobiyoloji Kliniği, Ankara.

${ }^{3}$ Ulucanlar Eye Educational and Research Hospital, Infectious Diseases and Clinical Microbiology Clinic, Ankara, Turkey.

${ }^{4}$ istanbul Üniversitesi Cerrahpaşa Tıp Fakültesi, Tıbbi Mikrobiyoloji Anabilim Dalı, İstanbul.

${ }^{4}$ Istanbul University Cerrahpasa Faculty of Medicine, Department of Medical Microbiology, Istanbul, Turkey.
}

* Bu çalışma, EKMUD 2013 Bilimsel Platformu (20-24 Mart 2013, Antalya)'nda poster bildiri olarak sunulmuştur.

Geliş Tarihi (Received): 11.04.2013• Kabul Ediliş Tarihi (Accepted): 26.06.2013

\section{ÖZET}

Tatarcık humması, tatarcık sineğinin (Phlebotomus) ısırmasıyla insanlara bulaşan bir enfeksiyon hastalığıdır. Hastalık genellikle üç gün sürer ve titreme, yüksek ateş, baş ağrısı, bulantı, kusma ve miyalji ile seyreder. Etkeni, Bunyaviridae ailesi, Phlebovirus cinsi içinde yer alan tatarcık ateşi virusu (Sandfly Fever virus, SFV)'dur. Toskana virus (TOSV) da, Sicilya ve Napoli virusları gibi SFV'nin bir serotipidir. Seroprevalans çalışmaları, SFV enfeksiyonlarının asemptomatik veya hafif semptomlarla geçirilebildiğini desteklemektedir. Ülkemizden TOSV enfeksiyonuyla ilgili bildirimler, kısıtlı sayıda bölgeden seroprevalans çalışmaları, kan donörü taramaları ve meningoensefalit tanısı ile takip edilmiş ancak etken saptanamamış hastaların saklanan beyin-omurilik sıvılarında viral RNA'nın tespiti ile sınırlıdır. Bu raporda, tanısı akut hastalık sırasında konulan ve eş zamanlı olarak HIV pozitifliği de saptanan ülkemizdeki ilk TOSV enfeksiyonu olgusu sunulmaktadır. Yüksek ateş, baş ağrısı ve halsizlik şikayetleri ile polikliniğimize başvuran 42 yaşındaki erkek hastanın, İstanbul'da yaşadığı ve şikayetlerinin Adana'ya gelmeden önce başladığı öğrenilmiştir. İstanbul'da ormanlık bir bölgeye yakın yerde ikamet ettiği belirlenen hastada, kene, sinek veya başka bir hayvan teması öyküsü bulunmamıştır. Hasta, yüksek ateşle birlikte, lökopeni, anemi ve trombositopeni gibi laboratuvar bulgularının olması nedeniyle hastaneye yatırılmışır. Yatışında alınan serum örnekleri, Kırım-Kongo kanamalı ateşi (KKKA) ve tatarcık humması yönünden araştııılmak üzere, Türkiye Halk Sağlığı Kurumu Ulusal Arbovirus ve Viral Zoonotik Hastalıklar Ünitesi Laboratuvarına gön-

IIletişim (Correspondence): Uzm. Dr. Ferit Kuşcu, Adana Numune Eğitim ve Araştırma Hastanesi, Enfeksiyon Hastalıkları ve Klinik Mikrobiyoloji Kliniği, Ege Bagatur Bulvarı, Yüreğir, Adana, Türkiye. Tel (Phone): +90 322355 0101/5381,

E-posta (E-mail): feritkuscu@gmail.com 
derilmiştir. Anti-HIV antikorlarının ELISA testi ile iki kez pozitif saptanması üzerine, sonuç Western Blot testi ile doğrulanmıştır. Günler içerisinde ateşi düşen ve şikayetleri azalan hastanın, trombosit değerleri de yükselmiştir. Hasta serumunda KKKA virusuna yönelik PCR ve ELISA IgM testleri ile SFV serotiplerine yönelik IgM ve IgG immünofloresan antikor (IFA) testleri negatif bulunurken, TOSV serotipine yönelik gerçek zamanlı ters transkriptaz PCR yöntemi ile pozitif sonuç alınmıştır. Serokonversiyon takibi için üç hafta sonra gönderilen serum örneğinde, IFA testi ile SFV Toskana ve Napoli serotiplerine karşı lgG antikorlarının pozitifleştiği saptanmıştır. Sonuç olarak, TOSV enfeksiyonu sıklıkla asemptomatik seyretmesine rağmen nadiren de olsa ciddi meningoensefalit tablosuna yol açabileceğinden, ülkemizin endemik bölgelerinde, yüksek ateş ve meningoensefalit bulguları olan hastaların ayırıı tanııında, TOSV'nin mutlaka dikkate alınması gerektiği düşünülmüştür.

Anahtar sözcükler: Toskana virus; tatarcık ateşi; HIV.

\section{ABSTRACT}

Sandfly fever is an infectious disease transmitted to people through sandfly bites. It usually takes three days and causes chills, high fever, headache, nausea-vomiting and myalgia. The causative agent, namely sandfly fever virus (SFV), is a member of the Bunyaviridae family, Phlebovirus genus. Toscana virus (TOSV) is a serotype of SFV, as so Sicilian and Naples viruses. Seroprevalence studies have demonstrated that SFV infections which have mild symptoms or asymptomatic, can be overcome. Studies concerning TOSV infections in Turkey are limited to a small number of regional seroprevalence surveys, blood-donor screening studies and detection of viral RNA in previously collected cerebrospinal fluid samples of suspected meningoencephalitis patients in whom no causative agents were identified. In this report from Turkey, the first acute case of TOSV infection diagnosed in a patient with HIV seropositivity, was presented. A 42-year-old male patient was admitted to Numune Research and Training Hospital Adana, Turkey with high fever, headache and malaise. The patient who lived in an area near to a forest in Istanbul, had no contact history with ticks, mosquitoes and other animals. He stated that he had had the symptoms before arriving to Adana. The patient was hospitalized due to leucopenia, anemia, and thrombocytopenia accompanying high fever. Serum samples were sent to National Arbovirus and Viral Zoonotic Diseases Unit of the Turkish Public Health Institute, for the detection of Crimean-Congo haemorrhagic fever (CCHF) virus and SFV. Western Blot test was run to confirm the presence of anti-HIV antibodies detected twice with ELISA. In the following days, the patient's fever and symptoms decreased, and thrombocyte levels increased. Although CCHF virus PCR and ELISA IgM tests as well as SFV IgM and IgG immunofluorescence antibody (IFA) tests were negative, real time reverse transcriptase PCR test yielded a positive result for TOSV. SFV IgG antibodies against Toscana and Naples viruses were found to be positive in the serum sample collected at the end of a three-week follow-up. Even though TOSV infection is usually known to have an asymptomatic clinical course, it may rarely lead to serious manifestations like meningoencephalitis. In our country where SFV is endemic, TOSV should be considered in the differential diagnosis of patients presenting with high fever and meningoencephalitis symptoms.

Key words: Toscana virus; sandfly fever; HIV.

\section{Giriş}

Arbovirus (Arthropod-Borne virus; eklem bacaklı kaynaklı viruslar) enfeksiyonlarından en önemlilerine Bunyaviridae ailesinin üyeleri neden olmaktadır. Bu ailenin Phlebovirus cinsi içerisinde bulunan tatarcık ateşi virusu (Sandfly Fever Virus; SFV), insanlara tatarcık sineğinin (Phlebotomus) ısırması sonucu bulaşmaktadır. Üç gün ateşi, Papatasi ateşi adlarıyla da bilinen tatarcık humması, ateş, retroorbital ağrı, miyalji, halsizlik gibi grip 
benzeri belirtilere neden olur ve hastalarda çoğunlukla bir hafta içinde tamamen iyileşme görülür. Toscana virus (TOSV) da, Sandfly Fever Napoli Virus (SFNV) ve Sandfly Fever Sicilya Virus (SFSV) ile birlikte, SFV'nin bir serotipidir. Seroprevalans çalışmaları TOSV enfeksiyonlarının, asemptomatik veya hafif semptomlarla geçirilebildiğini desteklemektedir. Çoğu olguda, TOSV enfeksiyonu kendini sınırlayan hafif bir hastalık şeklinde seyrederken, bazı olgularda santral sinir sistemi (SSS) bulgularıyla şiddetli bir hastalık tablosu oluşturabilmektedir. Yapılan çalışmalarda, İtalya'da yaz aylarında görülen aseptik menenjit olgularının \%80'inden bu virusun sorumlu olduğu bildirilmektedir ${ }^{1,2}$. Bu olgu sunumunda, HIV pozitifliğiyle eş zamanlı olarak akut TOSV enfeksiyonu tespit edilen hastanın, klinik ve laboratuvar bulguları, ülkemizdeki ve dünyadaki veriler eşliğinde değerlendirilmiştir.

\section{OLGU SUNUMU}

Kırk iki yaşında erkek hasta, yüksek ateş, baş ağrısı ve halsizlik şikayetleriyle hastanemizin enfeksiyon hastalıkları polikliniğine başvurdu. Öyküsünden, İstanbul'da yaşadığı ve şikayetlerinin beş gün önce, Adana'ya gelmeden başladığı öğrenildi. Yapılan ilk fizik muayenesinde hastanın ateşi $38.6^{\circ} \mathrm{C}$, bilinci açık, kooperasyonu ve oryantasyonu tamdı ve ense sertliği yoktu. Diğer muayene bulguları normaldi. Hemogram incelemesinde lökosit sayısı 3.700/mm $\mathrm{mm}^{3}$, hemoglobin $11.3 \mathrm{~g} / \mathrm{dl}$ ve trombosit sayısı $60.000 / \mathrm{mm}^{3}$ olması nedeniyle hasta enfeksiyon hastalıkları kliniğine yatırıldı. Laboratuvar bulguları; C-reaktif protein (CRP) $12.1 \mathrm{mg} / \mathrm{dl}$, aspartat aminotransferaz (AST) $25 \mathrm{IU} / \mathrm{L}$ ve alanin aminotransferaz (ALT) $12 \mathrm{IU} / \mathrm{L}$ olarak saptandı. Hastanın öyküsü derinleştirildiğinde İstanbul'un merkez ilçelerinden birinde ve ormanlık bir bölgeye yakın yaşadığı; son bir aydır kırsal bir alanı ziyaret etmediği; kene, sinek ve başka herhangi bir hayvan temasının olmadığı öğrenildi. Yatışının ilk gününde hastadan alınan serum örnekleri, Kırım-Kongo kanamalı ateşi (KKKA) ve tatarcık humması ön tanılarıyla çalışılmak üzere Türkiye Halk Sağlığı Kurumu, Mikrobiyoloji Referans Laboratuvarları Daire Başkanlığı, Ulusal Viroloji Referans Merkez Laboratuvarı Arbovirus ve Viral Zoonotik Hastalıklar Ünitesi Laboratuvarına gönderildi. Hastanın trombosit değerleri yatışının ikinci gününde 33.000/mm³ e düştü. Koagülometrik testleri normaldi. Retrobulber bölgede baş ağrısı şikayeti olan hastanın ateşi, $38^{\circ} \mathrm{C}$ olarak devam etmekteydi. Üçüncü gün istenen anti-HIV testinin, ELISA yöntemiyle iki kez pozitif sonuç vermesi üzerine, hasta serumu, Western Blot (WB) doğrulama testi yapılmak üzere Türkiye Halk Sağlığı Kurumu, Mikrobiyoloji Referans Laboratuvarları Daire Başkanlığı, Ulusal Viroloji Referans Merkez Laboratuvarlarına gönderildi. Yeni başlayan öksürük ve balgam şikayetleri de olması nedeniyle, kültürleri alındıktan sonra hastaya ampirik olarak seftriakson ve klaritromisin tedavisi başlandı. Takipleri sırasında ateşi düşen, şikayetleri azalan hastanın günler içinde trombosit değerleri yükseldi (167.000/ $\mathrm{mm}^{3}$ ). Yattığı gün gönderilen KKKA için IgM, IgG ve PCR sonuçları negatif olarak bildirildi. Klinik takibi sırasında alınan kültürlerinde üreme tespit edilmedi. Semptomatik tedaviyle ateşi düşen, bulguları gerileyen hasta kontrole gelmek üzere yatışının 11 . gününde taburcu edildi. 
Hastanın, referans laboratuvarına gönderilen serum örneğinden $400 \mu$ l alınarak, ticari ekstraksiyon kiti (EZ1 Virus Mini Kit v2.0, Qiagen, Almanya) ve otomatize sistem (EZ1 Advanced XL, Japonya) ile RNA ekstraksiyonu yapıldı. Gerçek zamanlı PCR (rtPCR) testi, Weidmann ve arkadaşları ${ }^{3}$ tarafından tanımlanan primer prob setleri ve Real Time PCR kiti (One Step Real Time PCR, Qiagen) kullanılarak Real Time PCR cihazında (Rotorgene 6000, Qiagen, Almanya) gerçekleştirildi. Ekstraksiyon ürünü, SFSV, SFNV ve TOSV serotiplerine ait nükleik asit dizilerinin varlığı açısından farklı reaksiyon tüplerinde ters transktiptaz PCR (RT-PCR) yöntemiyle $50^{\circ} \mathrm{C}^{\prime}$ de $30 \mathrm{dk}, 95^{\circ} \mathrm{C}^{\prime} \mathrm{de} 15 \mathrm{sn}$ ardından, $95^{\circ} \mathrm{C}^{\prime} \mathrm{de}$ 10 sn, $55^{\circ} \mathrm{C}^{\prime}$ de $30 \mathrm{sn}, 72^{\circ} \mathrm{C}^{\prime}$ de 10 sn 45 döngü ve ardından $72^{\circ} \mathrm{C}^{\prime}$ de 10 dakika tutularak her bir serotip için pozitif ve negatif kontrol eşliğinde aynı reaksiyon ortamında test edildi. Ticari mozaik indirekt immünofloresan antikor (IFA) testi (Euroimmun, Almanya) ile üretici firmanın önerileri doğrultusunda SFSV, SFCV, SFNV ve TOSV serotiplerine karşı oluşan IgM ve IgG antikorları açısından 1:100 dilüsyonda test edildi ve preparatlar, floresan mikroskop (Leica, Almanya) ile her bir serotip için ayrı ayrı alanlarda, floresans şiddetine göre bir pozitiften (+) dört pozitife (++++) kadar derecelendirilerek değerlendirildi. En çok alanda ve yüksek ışımayı veren serotip, kit önerileri doğrultusunda "olası etken serotip" olarak kaydedildi. Hastanın ilk serum örneğinde IFA testleri ile IgM ve IgG negatif olarak saptanırken, gerçek zamanlı RT-PCR testi ile TOSV serotipine yönelik pozitif sonuç alındı. Serokonversiyon takibi için üç hafta sonra gönderilen ikinci serum örneğinde, IFA testi ile SFV'ye -özellikle Toskana serotipine- yönelik belirgin (+++) olmak üzere, Napoli serotipine (++) de yönelik IgG antikorlarının pozitifleştiği saptandı. WB doğrulama testi sonucu da pozitif gelen hasta HIV/AIDS için takip edilmek üzere bir üst merkeze yönlendirildi.

\section{TARTIŞMA}

Toskana virus, ilk kez 1971 yılında İtalya'da Phlebotomus perniciosus isimli tatarcıklardan izole edilmiştir. İtalya, Fransa, İspanya, Kıbrıs, Yunanistan, Portekiz ve Almanya hastalığın görüldüğü ülkeler arasındadır ${ }^{4}$. Türkiye'de ise tatarcık humması ile ilgili ilk veriler, 1955 yılında Antalya ilinden toplanan serum örneklerinde elde edilmiş; SFSV ve SFNV sıklığı sırasıyla \%22 ve \%62 olarak bildirilmiştir ${ }^{5}$. Serter ${ }^{6}$ tarafından 1980 yılında Ege bölgesinde yapılan seroprevalans çalışmasında da, yine SFSV ve SFNV varlığı tespit edilmiştir. Ülkemizde tatarcık hummasıyla ilgili veriler oldukça sınırlı olmasına rağmen, son yıllarda yaşanan salgınlar ve bu alandaki duyarlılığın artmasıyla birlikte, çalışma sayılarında da bir artış görülmektedir. Torun ve arkadaşları ${ }^{7}$ tarafından, Kırıkkale'de ortaya çıkan tatarcık humması salgınında, serolojik olarak değerlendirilen 11 hastanın beşinde Napoli, üçünde ise Sicilya serotipine karşı lgM tespit edilmiştir. Adana, İzmir ve Ankara illerinde tatarcık humması şüpheli salgınlar sırasında değerlendirilen 106 örneğin \%38'inde SFSV, \%12'sinde SFSV/Sandfly Fever Cyprus Fever Virus (SFCV) ve \%4'ünde SFCV IgM pozitifliği saptanmıştır. Ayrıca bu çalışmada Sandfly Fever Turkish Virus (SFTV) adı verilen yeni bir virus tipi tanımlanmıştır ${ }^{8}$. 
Ergünay ve arkadaşları $^{9}$ tarafından 2011 yılında, Ankara, Konya, Eskiş̧ehir ve Zonguldak'tan, 1533 kan donöründe yapılan SFV aktivitesinin araştırıldığı çalışmada, IFA testiyle IgG pozitiflik oranı \%32.9 olarak bulunmuştur. Ayrıca bu çalışmada, etkeni belli olmayan SSS enfeksiyonu olan 102 hastadan 16'sının BOS örneklerinde ilk kez TOSV RNA varlığı tespit edilmiş ve bu tip hastalarda TOSV varlığının da akılda bulundurulması gerektiği vurgulanmıştır ${ }^{9}$. Bizim hastamızda, baş ağrısı dışında SSS enfeksiyonu bulguları olmayıp, ılımlı bir klinik seyirle hastanın şikayetleri gerilemiştir.

Özbel ve arkadaşlarının ${ }^{10}$ çalışmasında, 2003 yılında Akbük ve Olukbaşı'nda SFNV ve TOSV aktivitesi tespit edilmiş, ancak akut olgu bildirilmemiştir. Literatür taraması sonucunda, Ergünay ve arkadaşlarının ${ }^{9,11}$ etkeni belli olmayan, SSS enfeksiyonu tanılı hastaların saklanmış BOS örneklerinin bir kısmında tespit ettikleri TOSV RNA pozitifliği dışında, ülkemizdeki bütün veriler, sağlıklı kişilerden alınan kanlarla yapılan seroprevalans çalışmalarının sonucudur. Bizim hastamız ise, bilgilerimize göre Türkiye'den akut hastalık esnasında tanısı konmuş, SSS enfeksiyonu bulgusu olmadan tespit edilen ilk akut TOSV enfeksiyonudur. TOSV enfeksiyonları, kısa süreli klinik seyir göstermesine rağmen, bizim hastamızda şikayetler başladıktan altı gün sonra alınan serum örneğinde TOSV RNA pozitifliğinin saptanması, hastada aynı zamanda HIV pozitifliğinin de olmasına bağlanabilir. HIV enfeksiyonuna bağlı olarak gelişen immün sistemdeki zayıflama, hastalığın klinik bulgu vermesine ve TOSV viremisinin uzayarak, virusun PCR ile tespit edilmesine neden olmuş olabilir.

Hastanın şikayetlerinin Adana'ya gelmeden önce başlamış olması, virusun olasılıkla İstanbul kökenli bir virus olduğunu düşündürmektedir. Literatürde daha önce, İstanbul ilinden tatarcık humması ile ilgili bildirim bulunmamaktadır. Ancak bizim olgumuz ile eş zamanlı olarak, Erdem ve arkadaşları ${ }^{12}$, Tekirdağ ve Edirne illerini kapsayan Trakya bölgesindeki çalışmalarında, toplam üç olguda TOSV enfeksiyonu tespit etmişlerdir. Bu çalışmadaki olgular ve bizim olgumuzun da desteklediği veriler ışığında Trakya bölgesinde yapılacak daha geniş seroprevalans araştırmaları ve TOSV vektörlerine yönelik çalışmalar, hastalığın bölgedeki aktivitesinin gösterilmesi için faydalı olacaktır.

TOSV için vektörler, P.perniciosus ve P.perfiliewi türü tatarcıklardır ${ }^{1}$. Avrupa Hastalık Korunma ve Kontrol Merkezi (European Centre for Disease Prevention and Control) tarafından yürütülen VBORNET projesi kapsamında, Avrupa genelinde vektör artropodların sürveyansı yapılmaktadır ${ }^{1,13}$. Bu sürveyans verilerine göre ülkemizde P.perniciosus türü tatarcıklar bulunmazken; bazı illerimizde yapılan saha çalışmalarında P.perfiliewi türü tespit edilmiştir. Ancak bu tatarcık türüne ait veriler oldukça kısıtlıdır ve çoğu bölgemizde veri bulunmamaktadır ${ }^{14}$. Ülkemizde, TOSV için vektör olduğu bilinen P.perfiliewi ile ilgili saha çalışmalarının genişletilmesi ve toplum temelli seroprevalans çalışmalarının artmaSı, TOSV epidemiyolojisi ile ilgili bilgilerimizin artmasını sağlayacaktır. Bu veriler yeterli düzeye ulaşıncaya kadar, özellikle tatarcık hummasının endemik olduğu bölgelerde, yüksek ateş ve meningoensefalit bulguları olan hastaların ayırıcı tanısında TOSV enfeksiyonu mutlaka göz önünde bulundurulmalıdır. 


\section{KAYNAKLAR}

1. Depaquit J, Grandadam M, Fouque F, Andry PE, Peyrefitte C. Arthropod-borne viruses transmitted by Phlebotomine sandflies in Europe: a review. Euro Surveill 2010; 15(10): 19507.

2. Valassina M, Cusi MG, Valensin PE. A Mediterranean arbovirus: the Toscana virus. J Neurovirol 2003; 9(6): 577-83.

3. Weidmann M, Sanchez-Seco MP, Sall AA, et al. Rapid detection of important human pathogenic Phlebovirus. J Clin Virol 2008; 41(2): 138-42.

4. Charrel RN, Gallian P, Navarro-Mari JM, et al. Emergence of Toscana virus in Europe. Emerg Infect Dis 2005; 11(11): 1657-63.

5. Tesh RB, Saidi S, Gajdamovic SJ, Rodhain F, Vesenjak-Hirjan J. Serological studies on the epidemiology of sandfly fever in the Old World. Bull World Health Organ 1976; 54(6): 663-74.

6. Serter D. Present status of arbovirus sero-epidemiology in the Aegean region of Turkey. Zentralbl Bakteriol 1980; 270(Suppl 9): 155-61.

7. Torun Edis C, Yağcı Çağlayık D, Uyar Y, Korukluoğlu G, Ertek M. Kırıkkale ilinde saptanan tatarcık humması salgını. Mikrobiyol Bul 2010; 44(3): 431-9.

8. Carhan A, Uyar Y, Ozkaya E, et al. Characterization of a new new phlebovirus related to Sandfly fever Sicilian virus isolated during a sandfly fever epidemic in Turkey. J Clin Virol 2010; 48(4): 264-9.

9. Ergunay K, Saygan MB, Aydogan S, et al. Sandfly fever virus activity in central/northern Anatolia, Turkey: first report of Toscana virus infections. Clin Microbiol Infect 2011; 17(4): 575-81.

10. Ozbel Y, Ertabaklar H, Ciufolini MG, et al. Sandfly Fever viruses (Phleboviruses) transmitted by phlebotomus in Turkey. Microbiologia Balkanica 2003, 3rd Balkan Conference of Microbiology, 4-6 September 2003, Istanbul, Turkey. Proceedings, pp:1152-5.

11. Ergunay K, Sayiner AA, Litzba N, et al. Multicentre evaluation of central nervous system infections due to Flavi and Phleboviruses in Turkey. J Infect 2012; 65(4): 343-9.

12. Erdem H, Ergünay K, Akata F ve ark. Trakya Bölgesinde Batı Nil ve Toskana virus koinfeksiyonlarının ilk bildirimi. EKMUD 2013 Platformu, 20-24 Mart 2013, Antalya. Platform Kitabı, s: 152.

13. European Centre for Disease Prevention and Control. VBORNET Plebotomine maps. Available at: www.ecdc. europa.eu/en/healthtopics/vectors/vector-maps/Pages/VBORNET_maps_sandflies.aspx

14. Alten B, Ozbel Y. Phlebotominae sand flies (Diptera: Psychodidae): Main vectors in Europe and their distribution with special emphasis for Turkey. VBORNET Newsletter 8, special issue 'SAND FLIES', July $2010 ; 1$. Available at: http://www.vbornet.eu/newsletters/VBORNET_NL08.pdf 